УДК 615.12:339.162(477.84)

DOI https://doi.org/10.11603/2312-0967.2020.2.11174

\title{
ОРГАНІЗАЦІЙНІ ОСОБЛИВОСТІ ФАРМАЦЕВТИЧНОГО ЗАБЕЗПЕЧЕННЯ НАСЕЛЕННЯ ТЕРНОПІЛЬСЬКОЇ ОБЛАСТІ
}

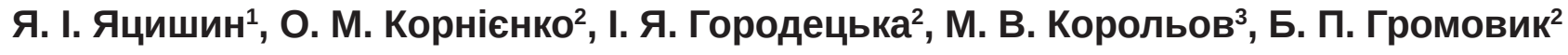 \\ ТзОВ «Аптека № 28 м. Львова» ${ }^{1}$ \\ Львівський національний медичний університет імені Данила Галицького 2 \\ Одеський національний медичний університет ${ }^{3}$ \\ yatsyshynaroslav123@ukr.net, lesyakorn@ukr.net, horodetska@gmail.com, Marat.korolev@ \\ gmail.com, hromovyk@gmail.com
}

\section{ІНФОРМАЦІЯ}

Надійшла до редакції / Received 10.04.2020

Після доопрацювання / Revised 27.04.2020

Прийнято до друку / Accepted: 28.04.2020

\section{Ключові слова:}

Тернопільська область; адміністративно-територіальні одиниці;

забезпечення аптечними закладами;

щільність населення.

\section{АНОТАЦІЯ}

Мета роботи. 3'ясування наявних організаційно-правових фрорм суб'єктів фрармацевтичного підприємництва та аналіз особливостей їхньої структури й локалізації в територіально-адміністративних одиницях Тернопільської області.

Матеріали і методи. Матеріали дослідження: Реєстр місць провадження діяльності з оптової та роздрібної торгівлі лікарськими засобами (Л3), статистичні дані щодо населення Тернопільської області. Використано методи інформаційного пошуку, системного і статистичного аналізу, порівняння та узагальнення.

Результати й обговорення. Встановлено, що на території Тернопільської області станом на 28.02.2020 р. з 290 суб'єктів підприємницької діяльності (СПД), які мають ліцензію на оптову і роздрібну торгівлю Л3, 257 зареєстровані в області, решта - в інших регіонах України. Фармацевтичне забезпечення здійснюють 4 аптечні склади, 523 аптеки та 99 аптечних пунктів. Майже три четвертих місць провадження діяльності з роздрібної реалізації Лз належать СПД, що зареєстровані у Тернопільській області. В містах зосереджено понад двох третіх, зокрема в м. Тернопіль - третина, від усіх місць провадження діяльності з роздрібної реалізації ЛЗ. Власниками майже половини аптечних закладів (АЗ) є фрізичні особи-підприємці (ФОП), понад двох п'ятих - товариства з обмеженою відповідальністю (ТзОВ), решта - комунальні та приватні підприємства і підприємства колективної власності. Ліцензію на виробництво ЛЗ мають лише 9 аптек. За забезпеченістю АЗ й щільністю населення адміністративно-територіальні одиниці Тернопільської області розподілилися на 8 з 10 кластерів за наявності кластера-лідера м. Тернопіль. Розподіл районів має значну асиметрію - низький рівень забезпечення АЗ характерний для трьох, а мала щільність населення - для семи районів із 17-ти.

Висновок. За результатами дослідження встановлено, що: фрармацевтичне забезпечення населення Тернопільської області здійснюють СпД різних організаційно-правових фрорм господарювання, більшість серед яких становлять ФОП і ТзОВ; порівняно з минулим роком кількість АЗ зменшилася внаслідок суттєвого скорочення місць провадження діяльності ФОП; частка мережевих аптек складає третину від усіх СПД фрармацевтичного ринку

ISSN 2312-0967. Фармацевтичний часопис. 2020. № 2 
Тернопільщини, а за кількістю місць провадження діяльності їх удвічі більше; у сільській місцевості розміщені менше третини АЗ, що перевищує аналогічний показник по Україні; лише 1,4 \% АЗ мають ліцензію на виробництво Л3, що на 0,2 \% менше, ніж в середньому по Україні; забезпечення АЗ у сільській місцевості у 2,8 раза нижче, ніж у міській; спостерігається суттєва дисеренціація адміністративно-територіальних одиниць за забезпеченістю АЗ й щільністю населення.

Вступ. Упродовж останніх років спостерігалося зростання забезпечення населення України аптечними закладами (АЗ), причому збільшення кількості місць провадження діяльності з роздрібної реалізації лікарських засобів (ЛЗ) відбувалося на тлі зниження чисельності населення [2]. На кінець 2018 р. в Україні налічувалося 23138 АЗ, у містах було зосереджено 73,1 \% місць провадження діяльності з роздрібної реалізації ЛЗ, власниками ліцензії на виробництво ЛЗ в умовах аптеки були лише 1,6 \%. Проте у 2019 р. ця тенденція дещо змінилася, позаяк протягом року було закрито 1254 місця провадження діяльності, на фрармацевтичному ринку припинили свою діяльність 438 ліцензіатів [1, 7].

Досить типовою для регіонів Західної України за системою розселення (більшість населення сконцентрована в містах) $є$ Тернопільська область. При цьому це територіально-адміністративна одиниця 3 аграрно-промисловим типом освоєння та з системою розселення зі значним переважанням сільських поселень (переважно малих і середніх), густою мережею малих міст і селищ міського типу, наявністю 1-2 великих міст $[5,6]$. Значна роздрібненість населених пунктів області ускладнює формування територіальної основи надання публічних послуг населенню, тому дослідження особливостей структури й локалізації суб'єктів підприємництва, що здійснюють фрармацевтичне забезпечення населення зазначеної вище області, $є$ актуальним.

Мета роботи. 3'ясування наявних організаційноправових фрорм суб'єктів орармацевтичного підприємництва та аналіз особливостей їх структури й локалізації у територіально-адміністративних одиницях Тернопільської області.

Матеріали і методи. Матеріали дослідження: Реєстр місць провадження діяльності з оптової та роздрібної торгівлі Л3 [4], статистичні дані щодо населення Тернопільської області $[5,6]$. Використано методи інфрормаційного пошуку, системного і статистичного аналізу, порівняння та узагальнення [3].

Результати й обговорення. Встановлено, що станом на 28.02.2020 р. в Україні налічується 22936 місць провадження діяльності з роздрібної реалізації л3. На території Тернопільської області 3290 суб'єктів підприємницької діяльності (СПД), які мають ліцензію на оптову і роздрібну торгівлю ЛЗ, 257 ліцензіатів зареєстровані у названій області, місцем державної реєстрації решти 33 СПД є інші регіони
України. Загалом фрармацевтичне забезпечення населення Тернопільській області здійснюють 626 АЗ, зокрема: 4 аптечних склади, 523 аптеки та 99 аптечних пунктів. Більшість місць провадження діяльності 3 роздрібної реалізації Л3 (72,8 \%) належить СПД, що зареєстровані лише у досліджуваній області. Решта 169 АЗ є власністю СПД, місцем державної реєстрації яких є інші регіони України [8].

Порівняно з минулим роком кількість СПД та місць провадження діяльності з роздрібної реалізації лЗ на Тернопільщині зменшилася відповідно на 12,1 \% і 4,6 \%, позаяк станом на 01.01.2019 р. на території названої області функціонувало 656 АЗ, з них 224 -у м. Тернополі.

За даними, наведеними в таблиці 1 , на даний час в обласному центрі зосереджено 215 АЗ, що складає 34,6 \% від усіх місць провадження діяльності з роздрібної реалізації ЛЗ в області. При цьому частка аптек і аптечних пунктів становить відповідно 84,1% і $15,9 \%$.

Щодо структури роздрібного фрармацевтичного ринку Тернопільської області, то частка мережевих аптек складає третину від усіх СПД (33,6 \%), а за кількістю місць провадження діяльності їх удвічі більше, позаяк загалом до них належать 66,4 \% А3.

Найбільшими аптечними мережами є ТзОВ «Подорожник» Тернопіль» (м. Львів) і «Тернопільське обласне виробниче аптечне об'єднання» (м. Тернопіль), що налічують у своїй структурі відповідно 44 і 36 АЗ. Від 11-ти до 35-ти місць провадження діяльності на Тернопільщині мають аптечні мережі: ТзОВ «Аптека «Зі», ТзОВ «ЛІДЕР-ЗАХІД» (Львівська обл., Пустомитівський район), мале колективне підприємство «Фармако» (Львівська обл., м. Дрогобич) і ТзОВ «Мішель» (Тернопільська обл., Чортківський район).

На даний час фрізичні особи-підприємці (ФОП) є власниками майже половини (48,0 \%) АЗ Тернопільщини. Зокрема, в обласному центрі їм належить 89 місць провадження діяльності з роздрібної реалізації Л3, причому упродовж попереднього року ця кількість зменшилася на 26 АЗ. Загалом у районах області цей показник знизився на 48 місць провадження діяльності, адже за межами м. Тернополя у власності ФОП залишилося 210 АЗ

Товариства з обмеженою відповідальністю (ТзОВ) складають 43,3 \% суб'єктів роздрібного фрармацевтичного ринку м. Тернополя, в області їх дещо менше $-26,0 \%$

ISSN 2312-0967. Pharmaceutical review. 2020. № 2 


\section{Організація роботи аптечних підприємств}

Organization of pharmaceutical structures' work

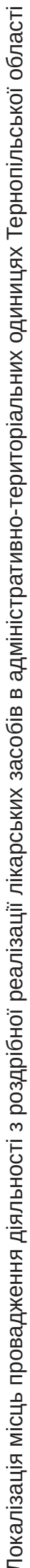

\begin{tabular}{|c|c|c|c|c|c|c|c|c|c|c|c|c|c|c|c|c|c|c|c|c|c|c|}
\hline \multirow{2}{*}{ 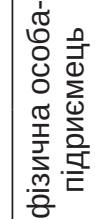 } & $\partial^{e}$ & $\begin{array}{l}\infty \\
\stackrel{N}{ }\end{array}$ & $\begin{array}{l}\mathscr{N} \\
\stackrel{2}{N}\end{array}$ & o & $\begin{array}{l}0 \\
0\end{array}$ & $\stackrel{m}{\sigma}$ & \begin{tabular}{l}
0 \\
\multirow{1}{*}{}
\end{tabular} & $\sigma_{j}$ & $\begin{array}{l}0 \\
0\end{array}$ & $\stackrel{m}{\sim}$ & $\stackrel{m}{m}$ & $\hat{i}$ & $\hat{0}^{-}$ & $\stackrel{m}{\sim}$ & $\hat{m^{-}}$ & $\bar{r}$ & $\begin{array}{l}0 \\
0\end{array}$ & $\hat{m}^{-}$ & $\begin{array}{l}0 \\
15\end{array}$ & $\tilde{i}$ & ○ & \\
\hline & ธ్ర & $\infty$ & 읏 & $m$ & $\stackrel{\infty}{\stackrel{-}{-1}}$ & $\stackrel{m}{\sim}$ & లి & $\stackrel{\checkmark}{\triangleleft}$ & $\stackrel{\infty}{\stackrel{-1}{-1}}$ & $r$ & 옥 & 각 & $\sim$ & $\lambda$ & $\exists$ & 10 & $\stackrel{\infty}{\rightarrow}$ & $\exists$ & $\stackrel{2}{\sim}$ & ( ) & 尺 & $\begin{array}{l}0 \\
\stackrel{\infty}{+} \\
\stackrel{+}{\sigma}\end{array}$ \\
\hline \multirow{2}{*}{ 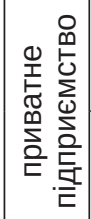 } & $\partial^{\circ}$ & $\begin{array}{l}0 \\
\text { mे }\end{array}$ & 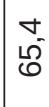 & - & 1 & - & & $\begin{array}{l}\infty \\
m^{-1}\end{array}$ & $\begin{array}{l}\infty \\
m^{-}\end{array}$ & G & s. & $\hat{N}$ & $\begin{array}{l}a \\
-i\end{array}$ & $\begin{array}{l}\infty \\
\omega^{\prime}\end{array}$ & $\begin{array}{l}\Omega \\
-i\end{array}$ & 1 & $\hat{N}$ & 1 & $\begin{array}{l}\infty \\
m^{-}\end{array}$ & 1 & 윽 & \\
\hline & ర் & $\stackrel{\infty}{\sim}$ & ले & 0 & 1 & 0 & -1 & $\sim$ & $N$ & 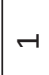 & $\neg$ & $\nabla$ & -1 & $m$ & -1 & 1 & $\checkmark$ & 1 & $N$ & 1 & กิ & $\stackrel{\nabla}{\infty^{\prime}}$ \\
\hline \multirow{2}{*}{$\begin{array}{l}\text { Oे } \\
\text { pe }\end{array}$} & $\partial^{\circ}$ & $\begin{array}{l}2 \\
\sigma^{\circ}\end{array}$ & $\begin{array}{l}m \\
\tilde{n} \\
\end{array}$ & 'ি & $\begin{array}{l}0 \\
0\end{array}$ & $\stackrel{0}{\circ}$ & $\stackrel{1}{\sim}$ & $\begin{array}{l}0 \\
10\end{array}$ & o & $\stackrel{0}{-1}$ & ח- & $\begin{array}{l}0 \\
10\end{array}$ & $\begin{array}{l}0 \\
\text { N }\end{array}$ & I & $\begin{array}{l}\infty \\
\tilde{m}\end{array}$ & 1 & $\stackrel{\sim}{\infty}$ & $\stackrel{\circ}{N}$ & مू & $\stackrel{2}{\sim}$ & 억 & \\
\hline & ర் & m & @ & 0 & $\underset{\sim}{\sim}$ & $\infty$ & م & 악 & & $\sim$ & $m$ & 악 & $\nabla$ & 1 & $\sim$ & 1 & N & $\nabla$ & $\stackrel{9}{\rightarrow}$ & ( ) & 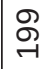 & 嗢 \\
\hline \multirow{2}{*}{5} & $\partial^{\circ}$ & $\infty$ & $\begin{array}{l}N \\
N \\
N\end{array}$ & $\stackrel{\infty}{-1}$ & $\begin{array}{l}\infty \\
\omega^{-}\end{array}$ & $\stackrel{\infty}{-1}$ & " & $\begin{array}{l}\infty \\
\infty \\
\infty\end{array}$ & m & $\begin{array}{l}\tilde{L} \\
\tilde{m}\end{array}$ & $\stackrel{0}{1}$ & $\begin{array}{l}10 \\
0 \\
0\end{array}$ & $\begin{array}{l}0 \\
N\end{array}$ & $\begin{array}{l}m \\
\omega^{\circ}\end{array}$ & $\begin{array}{l}\tilde{R} \\
\tilde{m}\end{array}$ & $\stackrel{\infty}{-1}$ & $\begin{array}{l}0 \\
N^{\prime}\end{array}$ & $\begin{array}{l}\infty \\
-i\end{array}$ & $\begin{array}{l}m \\
\underset{f}{m}\end{array}$ & $\infty$ & 암 & \\
\hline & ธ் & $\stackrel{10}{\rightarrow}$ & ถั & -1 & $a$ & -1 & $m$ & 10 & $m$ & $N$ & $\nabla$ & 0 & $\nabla$ & $m$ & $\sim$ & -1 & $\nabla$ & $\rightarrow$ & $\Lambda$ & -1 & $\stackrel{N}{N}$ & fi \\
\hline
\end{tabular}

赵

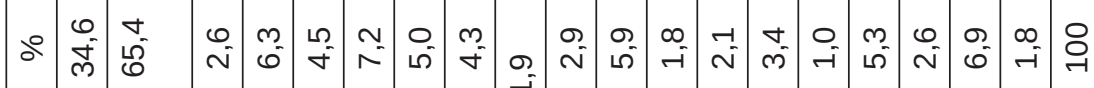

넌

চ்்

\begin{tabular}{|c|c|c|c|c|c|c|c|c|c|c|c|c|c|c|c|c|c|c|c|c|c|}
\hline$\stackrel{x}{\stackrel{x}{I}} \cdot \frac{\emptyset}{E}$ & $0^{\circ}$ & $\begin{array}{l}m \\
\tilde{m}\end{array}$ & $\hat{\theta}$ & $\begin{array}{l}0 \\
\text { N }\end{array}$ & $\underset{F}{N}$ & $\begin{array}{l}0 \\
\sigma\end{array}$ & 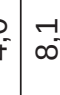 & \begin{tabular}{l|l}
7 \\
5
\end{tabular} & $\frac{\circ}{\circ}$ & O. & $\underset{f}{\circ}$ & $\stackrel{-1}{N}$ & 0 & $\stackrel{0}{-i}$ & \begin{tabular}{l}
0 \\
\multirow{f}{*}{}
\end{tabular} & $\begin{array}{l}0 \\
-i\end{array}$ & $\begin{array}{l}-1 \\
6\end{array}$ & $\stackrel{0}{\circ}$ & $\begin{array}{l}-1 \\
0^{-}\end{array}$ & $\stackrel{\circ}{i}$ & 윽 \\
\hline
\end{tabular}

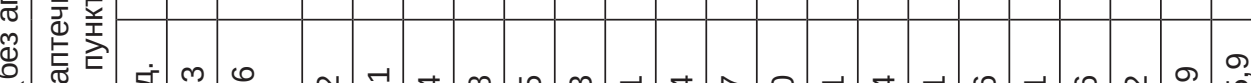

$\underset{m}{\stackrel{\varrho}{e}}$ 它 蒾

\begin{tabular}{|c|c|c|c|c|c|c|c|c|c|c|c|c|c|c|c|c|c|c|c|c|c|c|}
\hline 过 & $a^{0}$ & $\begin{array}{l}\infty \\
\text { ले }\end{array}$ & $\begin{array}{l}N \\
i n \\
0\end{array}$ & $\hat{N}$ & $\begin{array}{l}m \\
\omega^{-}\end{array}$ & $\begin{array}{l}0 \\
\nabla\end{array}$ & $\stackrel{-1}{r}$ & $\begin{array}{l}0 \\
15\end{array}$ & $\begin{array}{l}0 \\
\sigma^{-}\end{array}$ & $\stackrel{-1}{\sim}$ & $\hat{\sim}$ & $\sqrt{5}$ & $\stackrel{-1}{\sim}$ & $\stackrel{m}{\sim}$ & $\stackrel{N}{m}$ & $\begin{array}{l}\sigma \\
0\end{array}$ & $\begin{array}{c}N \\
N \\
\sim\end{array}$ & $\begin{array}{l}\text { S } \\
\text { N }\end{array}$ & $\stackrel{-}{N}$ & $\tilde{F}$ & 억 & \\
\hline & ธ் & $\underset{\sim}{\infty}$ & ને & $\stackrel{ナ}{\sqsupset}$ & $\stackrel{\infty}{\sim}$ & $\stackrel{\searrow}{\sim}$ & $\hat{m}$ & $\stackrel{\bullet}{v}$ & $\stackrel{\sim}{\sim}$ & $\exists$ & $\vec{\neg}$ & ஓి & $\exists$ & 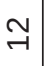 & ને & ما & $\hat{N}$ & $\stackrel{\sim}{\sim}$ & $\hat{m}$ & $\sigma$ & $\underset{N}{N}$ & $\begin{array}{l}-1 \\
+ \\
\infty\end{array}$ \\
\hline
\end{tabular}

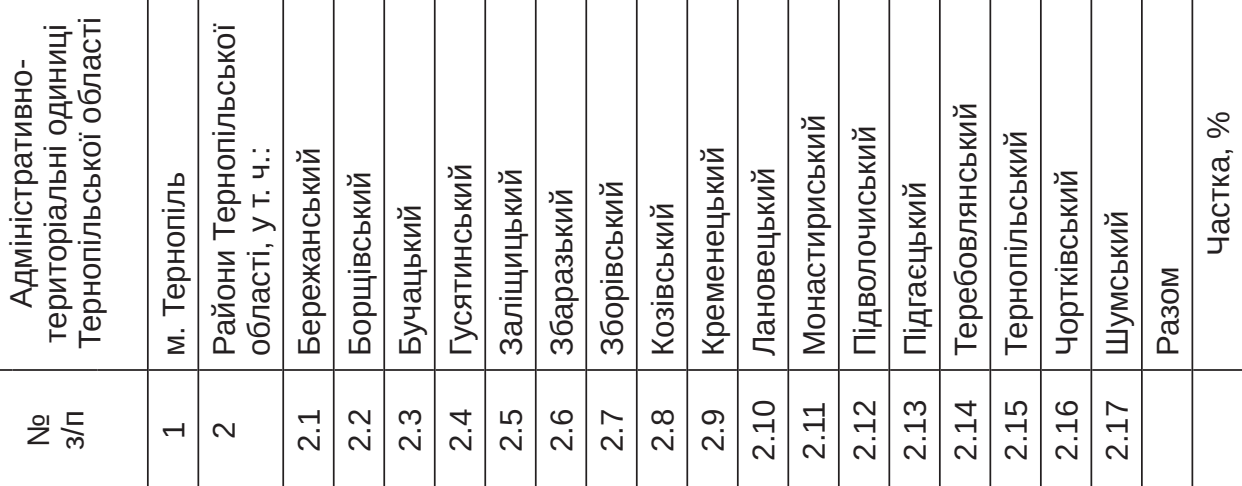

ISSN 2312-0967. Фармацевтичний часопис. 2020. № 2 
Організація роботи аптечних підприємств Organization of pharmaceutical structures' work

У структурі місць провадження діяльності з роздрібної реалізації ЛЗ спостерігається зростання частки ТзОВ в обласному центрі на 7,5 \%, за його межами - на 6,2 \% порівняно з минулим роком [6]. Частка комунальних АЗ в обласному центрі проти минулого року дещо зросла (від 6,6 \% до 7,0 \%), а в області загалом незначно знизилася (від 14,4\% до 14,0 \%). Решту роздрібного фрармацевтичного ринку складають приватні підприємства і підприємства колективної власності, частка яких у м. Тернополі та області упродовж року зросла відповідно на 1,8 \% і $0,9 \%$.
Ліцензію на виробництво (виготовлення) ЛЗ в умовах аптеки мають лише 9 аптек (1,4%), з них п'ять розташовані у м. Тернополі (табл. 2). При цьому лише одна аптека належить ТзОВ «Фірма «РутаФарм», решта є комунальними підприємствами (КП). Варто зауважити, що в Україні цей показник дещо вищий (1,6 \%), адже загалом таку ліцензію мають 324 аптеки.

Ще одним фррагментом дослідження був аналіз розміщення АЗ у різних типах населених пунктів адміністративно-територіальних районів досліджуваної області (табл. 3).

Таблиця 2

Перелік аптек Тернопільської області, що мають ліцензію на виробництво (виготовлення) лікарських засобів

\begin{tabular}{|c|c|c|c|}
\hline $\begin{array}{l}\text { № } \\
3 / \Pi\end{array}$ & Ліцензіат & Назва А3 & Адреса \\
\hline 1 & $\begin{array}{l}\text { КП «Тернопільська обласна } \\
\text { комунальна міжлікарняна аптека } \\
\text { № } 126 »\end{array}$ & $\begin{array}{l}\text { Тернопільська обласна } \\
\text { комунальна міжлікарняна } \\
\text { аптека № } 126\end{array}$ & $\begin{array}{l}\text { м. Тернопіль, } \\
\text { вул. Тролейбусна, } 14\end{array}$ \\
\hline 2 & $\begin{array}{l}\text { кП Тернопільської обласної ради } \\
\text { «Тернопільська обласна аптека } \\
\text { № 153» }\end{array}$ & $\begin{array}{l}\text { Тернопільська обласна } \\
\text { аптека № } 153\end{array}$ & $\begin{array}{l}\text { м. Тернопіль, } \\
\text { вул. Коновальця, } 8\end{array}$ \\
\hline 3 & $\begin{array}{l}\text { КП Тернопільської обласної ради } \\
\text { «Тернопільська обласна аптека № 78» }\end{array}$ & $\begin{array}{l}\text { Тернопільська обласна } \\
\text { аптека № } 78\end{array}$ & м. Тернопіль, вул. Руська, 23 \\
\hline 4 & $\begin{array}{l}\text { КП «Тернопільська обласна кому- } \\
\text { нальна міжлікарняна аптека № 157» }\end{array}$ & Аптека № 157 & $\begin{array}{l}\text { М. Тернопіль, } \\
\text { вул. Сахарова, } 2\end{array}$ \\
\hline 5 & ТзОВ «Фірма «Рута-Фарм» & Аптека № 103 & м. Тернопіль, просп. С. Бандери, 19 \\
\hline 6 & $\begin{array}{l}\text { КП «Борщівська обласна } \\
\text { комунальна центральна районна } \\
\text { аптека № 11» }\end{array}$ & ЦРА № 11 & $\begin{array}{l}\text { Тернопільська обл., м. Борщів, } \\
\text { вул. Гетьмана Мазепи, } 14\end{array}$ \\
\hline 7 & $\begin{array}{l}\text { КП «Чортківська обласна } \\
\text { комунальна центральна районна } \\
\text { аптека № 143» }\end{array}$ & ЦРА № 143 & $\begin{array}{l}\text { Тернопільська обл., м. Чортків, } \\
\text { вул. С. Бандери, } 20\end{array}$ \\
\hline 8 & $\begin{array}{l}\text { КП «Товстенська обласна } \\
\text { комунальна аптека № 24» }\end{array}$ & Аптека № 24 & $\begin{array}{l}\text { Тернопільська обл., Заліщицький } \\
\text { р-н., смт. Товсте, вул. Українська, } 94\end{array}$ \\
\hline 9 & $\begin{array}{l}\text { КП «Збаразька обласна комунальна } \\
\text { центральна районна аптека № 26» }\end{array}$ & Аптека № 138 & $\begin{array}{l}\text { Тернопільська обл., м. Збараж, } \\
\text { вул. Павлова, } 2\end{array}$ \\
\hline
\end{tabular}

Таблиця 3

Забезпечення аптечними закладами населення адміністративно-територіальних одиниць Тернопільської області

\begin{tabular}{|c|c|c|c|c|c|c|c|c|c|}
\hline \multirow{3}{*}{$\begin{array}{l}\text { № } \\
\text { 3/ח }\end{array}$} & \multirow{3}{*}{$\begin{array}{c}\text { Адміністративно- } \\
\text { територіальні } \\
\text { одиниці }\end{array}$} & \multirow{3}{*}{$\underset{\text { Kм² }^{2}}{\text { Площа, }}$} & \multirow{3}{*}{$\begin{array}{c}\text { Кількість } \\
\text { населення }\end{array}$} & \multicolumn{5}{|c|}{ Кількість АЗ у } & \multirow{3}{*}{$\begin{array}{c}\text { К-сть осіб } \\
\text { на } \\
\text { один АЗ }\end{array}$} \\
\hline & & & & \multicolumn{2}{|c|}{ містах } & \multicolumn{2}{|c|}{$\begin{array}{c}\text { сільській } \\
\text { місцевості }\end{array}$} & \multirow{2}{*}{ разом } & \\
\hline & & & & аптеки & $\begin{array}{l}\text { аптечні } \\
\text { пункти }\end{array}$ & аптеки & $\begin{array}{l}\text { аптечні } \\
\text { пункти }\end{array}$ & & \\
\hline 1 & 2 & 3 & 4 & 5 & 6 & 7 & 8 & 9 & 10 \\
\hline 1 & м. Тернопіль & 59 & 222491 & 182 & 33 & & & 215 & 1035 \\
\hline 2 & $\begin{array}{l}\text { Райони } \\
\text { Тернопільської } \\
\text { області, в т.ч.: }\end{array}$ & 13764 & 818482 & 193 & 30 & 147 & 36 & 406 & 2011 \\
\hline 2.1 & Бережанський & 661 & 39599 & 14 & 2 & - & - & 16 & 2474 \\
\hline 2.2 & Борщівський & 1006 & 65309 & 12 & 4 & 16 & 7 & 39 & 1675 \\
\hline
\end{tabular}

ISSN 2312-0967. Pharmaceutical review. 2020. № 2 
Організація роботи аптечних підприємств Organization of pharmaceutical structures' work

Продовження табл. 3

\begin{tabular}{|c|l|c|c|c|c|c|c|c|c|}
\hline 1 & \multicolumn{1}{|c|}{2} & 3 & 4 & 5 & 6 & 7 & 8 & 9 & 10 \\
\hline 2.3 & Бучацький & 802 & 62437 & 17 & 1 & 7 & 3 & 28 & 2230 \\
\hline 2.4 & Гусятинський & 1016 & 58226 & 17 & 4 & 20 & 4 & 45 & 1294 \\
\hline 2.5 & Заліщицький & 684 & 45189 & 14 & 3 & 12 & 2 & 31 & 1458 \\
\hline 2.6 & Збаразький & 863 & 56042 & 17 & 3 & 7 & - & 27 & 2076 \\
\hline 2.7 & Зборівський & 977 & 40152 & 6 & - & 5 & 1 & 12 & 3346 \\
\hline 2.8 & Козівський & 694 & 36561 & - & - & 14 & 4 & 18 & 2031 \\
\hline 2.9 & Кременецький & 918 & 66918 & 25 & 6 & 5 & 1 & 37 & 1809 \\
\hline 2.10 & Лановецький & 632 & 28563 & 8 & - & 3 & - & 11 & 2596 \\
\hline 2.11 & Монастириський & 558 & 26080 & 7 & - & 5 & 1 & 13 & 2006 \\
\hline 2.12 & Підволочиський & 837 & 40923 & 3 & - & 14 & 4 & 21 & 1949 \\
\hline 2.13 & Підгаєцький & 496 & 17643 & 3 & 1 & 1 & - & 5 & 3529 \\
\hline 2.14 & Теребовлянський & 1130 & 63274 & 15 & 2 & 12 & 4 & 33 & 1917 \\
\hline 2.15 & Тернопільський & 749 & 67114 & - & - & 15 & 1 & 16 & 4195 \\
\hline 2.16 & Чортківський & 903 & 71655 & 27 & 3 & 10 & 3 & 43 & 1666 \\
\hline 2.17 & Шумський & 838 & 32797 & 8 & 1 & 1 & 1 & 11 & 2981 \\
\hline Разом & 13823 & 1040973 & 376 & 63 & 147 & 36 & 622 & 1673 \\
\hline
\end{tabular}

Загалом на території Тернопільської області $71,9 \%$ аптек і 63,6 \% аптечних пунктів (або понад двох третіх (70,6 \%) АЗ) знаходяться у міській місцевості, що означає нерівномірне забезпечення населення АЗ. Так, у сільській місцевості на один АЗ у середньому припадає 3003 осіб, у міській -1074. Це при частці сільського населення 54,7 \% та міського 45,3 \% [3]. Отож, забезпечення АЗ у сільській місцевості у 2,8 раза нижча, ніж у міській.

Завершальним етапом дослідження було диференціювання адміністративно-територіальних одиниць Тернопільської області на підставі ієрархічної кластеризації за забезпеченням АЗ і щільністю населення (рис. 1).

За даними рисунка 1, спостерігали суттєву територіальну диференціацію, позаяк адміністративно-територіальні одиниці розподілилися на 8 з 10 кластерів, зокрема, кластером-лідером було м. Тернопіль, а до 7 кластера («високе забезпечення АЗ - велика щільність населення») увійшов лише Тернопільський район. Також лише один Бережанський район розміщено в кластері 5 «середнє забезпечення АЗ - середня щільність населення».

По два райони згруповано в кластерах 1 «низьке забезпечення АЗ - мала щільність населення» і 2 «середнє забезпечення АЗ - мала щільність населення». Три райони згруповано в кластер 3 «високе забезпечення АЗ - мала щільність населення», п'ять - у кластер 6 «високе забезпечення АЗ - середня щільність населення», ще три - в кластер 9 «високе забезпечення АЗ - велика щільність населення».
Розподіл районів за окремими аналізованими чинниками має значну асиметрію - низький рівень забезпечення АЗ характерний для трьох районів $(17,6 \%)$, а мала щільність населення - для семи районів (41,2\%).

Головна причина цієї дифреренціації полягає в нерівномірності соціально-економічного розвитку районів.

Висновок. За результатами дослідження встановлено, що:

- фрармацевтичне забезпечення населення Тернопільської області здійснюють СПД різних організаційно-правових форм господарювання, більшість серед яких становлять ФОП і ТзОВ;

- порівняно 3 минулим роком кількість АЗ зменшилася внаслідок суттєвого скорочення місць провадження діяльності ФОП;

- частка мережевих аптек складає третину від усіх СпД фрармацевтичного ринку Тернопільщини, а за кількістю місць провадження їхньої діяльності удвічі більше;

- у сільській місцевості розміщені менше третини А3, що перевищує аналогічний показник по Україні;

- лише 1,4 \% АЗ мають ліцензію на виробництво Л3, що на 0,2 \% менше, ніж в середньому по Україні;

- забезпечення АЗ у сільській місцевості у 2,8 раза нижча ніж у міській;

- спостерігається суттєва дисеренціація адміністративно-територіальних одиниць за забезпеченням АЗ й щільністю населення.

Конфолікт інтересів: відсутній.

Conflict of interest: authors have no conflict of interest to declare.

ISSN 2312-0967. Фармацевтичний часопис. 2020. № 2 
Організація роботи аптечних підприємств

Organization of pharmaceutical structures' work

\begin{tabular}{|c|c|c|c|c|}
\hline \multicolumn{5}{|c|}{$\begin{array}{c}\text { Кластер-лідер: } \\
\text { м. Тернопіль }(1035 / 3771)\end{array}$} \\
\hline \multirow{3}{*}{ 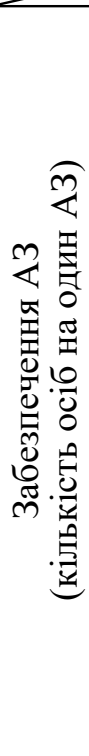 } & 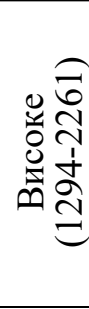 & $\begin{array}{c}\text { Кластер } 3 \\
\text { (3 райони): } \\
\text { Підволочиський } \\
(1949 / 49) \\
\text { Козівський }(2031 / 53) \\
\text { Монастириський } \\
\text { (2006/47) }\end{array}$ & $\begin{array}{c}\text { Кластер 6 } \\
\text { (5 районів): } \\
\text { Гусятинський }(1294 / 57) \\
\text { Заліщицький }(1458 / 66) \\
\text { Борщівський }(1675 / 65) \\
\text { Теребовлянський }(1917 / 56) \\
\text { Збаразький }(2076 / 65)\end{array}$ & $\begin{array}{c}\text { Кластер } 9 \\
(3 \text { райони): } \\
\text { Чортківський }(1666 / 79) \\
\text { Кременецький } \\
(1809 / 73) \\
\text { Бучацький }(2230 / 78)\end{array}$ \\
\hline & 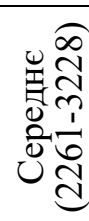 & $\begin{array}{c}\text { Кластер } 2 \\
\text { (2 райони): } \\
\text { Шумський }(2981 / 39) \\
\text { Лановецький }(2596 / 45)\end{array}$ & $\begin{array}{c}\text { Кластер } 5 \\
(1 \text { район }) \\
\text { Бережанський }(2474 / 60)\end{array}$ & $\begin{array}{l}\text { Кластер } 8 \\
\text { (немає) }\end{array}$ \\
\hline & 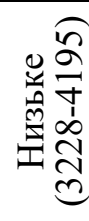 & $\begin{array}{c}\text { Кластер 1 } \\
\text { (2 райони) } \\
\text { 3борівський }(3346 / 41) \\
\text { Підгаєцький }(3529 / 36)\end{array}$ & $\begin{array}{c}\text { Кластер } 4 \\
\text { (немає) }\end{array}$ & $\begin{array}{c}\text { Кластер } 7 \\
\text { (1 район): } \\
\text { Тернопільський } \\
\quad(4195 / 90)\end{array}$ \\
\hline \multirow{2}{*}{\multicolumn{2}{|c|}{2020}} & Мала (36-54) & Середня (54-72) & Велика (72-90) \\
\hline & & \multicolumn{3}{|c|}{ Щільність населення (кількість осіб на один кв. м.) } \\
\hline
\end{tabular}

Рис. 1. Диференціація адміністративно-територіальних одиниць Тернопільської області за щільністю населення і забезпечення аптечними закладами.

\title{
ORGANIZATIONAL PECULIARITIES OF PHARMACEUTICAL SUPPORT FOR THE POPULATION OF TERNOPIL OBLAST
}

\author{
Y. I. Yatsyshyn ${ }^{1}$, O. M. Korniyenko², I. Ya. Horodetska², M. V. Korolyov³, B. P. Hromovyk ${ }^{2}$ \\ ${ }^{1}$ LLC Pharmacy No. 28, Lviv \\ ${ }^{2}$ Danylo Halytsky Lviv National Medical University \\ ${ }^{3}$ Odesa National Medical University \\ yatsyshynaroslav123@ukr.net, lesyakorn@ukr.net,horodetska@gmail.com, Marat.korolev@gmail.com, \\ hromovyk@gmail.com
}

The aim of the work. Establishing the existing organizational and legal forms of the subjects of pharmaceutical business and analysis of the peculiarities of their structure and localization in the territorial-administrative units of Ternopil oblast.

Materials and Methods. Materials of the study: Register of locations for wholesale and retail trade of drugs, statistics on the population of Ternopil oblast. The methods of information search, systematic and statistical analysis, comparison and generalization have been used.

Results and Discussion. It has been found that in Ternopil oblast as of February 28, 2020, 257 out of 290 business entities, which are licensed for wholesale and retail trade of medicines are registered on the territory of the region, the rest - in other regions of Ukraine. Pharmaceutical supply is provided by 4 pharmacy warehouses, 523 pharmacies and 99 limited-service pharmacies. Almost three-fourths of places for retail sales of medicines belong to business entities registered in Ternopil oblast. In cities, more than two-thirds of all places of retail sales of medicines are concentrated (including the city of Ternopil - one third). Almost half of the pharmaceutical establishments (PEs) are owned by natural person-entrepreneur (NPE), over two-fifths are limited liability companies (LLC), and the rest are utility and private enterprises. Only 9 pharmacies are licensed to manufacture drugs. The administrative and territorial units of Ternopil oblast were divided into 8 out of 10 clusters by provision of PEs and population density with the presence of a cluster leader - the city of Ternopil. The distribution of districts has a significant asymmetry - the low level of provision of PEs is characteristic for three, and the low population density - for seven out of 17 districts.

ISSN 2312-0967. Pharmaceutical review. 2020. № 2 
Організація роботи аптечних підприємств

Organization of pharmaceutical structures' work

Conclusion. According to the results of the study, it has been established that: pharmaceutical support for the population of Ternopil oblast are provided by business entities of various organizational and legal forms of management, most of which are NPE and LLC; compared to last year, the number of PEs decreased as a result of a significant reduction in the NPE's activity locations; the share of pharmaceutical networks is one third of the all business entities of pharmaceutical market in Ternopil oblast, and the number of places of their activity is twice as big; in rural areas less than one third of the PEs are located, which exceeds the same indicator in other regions of Ukraine; only $1.4 \%$ of PEs are licensed to manufacture medicines, which is $0.2 \%$ less than the average in Ukraine; the provision of PEs in rural areas is 2.8 times lower than in urban areas; there is a significant differentiation of administrative-territorial units in terms of provision of PEs and population density.

Key words: Ternopil oblast; administrative-territorial units; provision of pharmaceutical establishments; population density.

\section{ОРГАНИЗАЦИОННЫЕ ОСОБЕННОСТИ ФАРМАЦЕВТИЧЕСКОГО ОБЕСПЕЧЕНИЯ НАСЕЛЕНИЯ ТЕРНОПОЛЬСКОЙ ОБЛАСТИ}

\section{Я. И. Яцишин ${ }^{1}$, А. М. Корниенкоㄹ, И. Я. Городецкая², М. В. Королев ${ }^{3}$ Б. П. Громовик²}

ООО «Аптека № 28 г. Львова» ${ }^{1}$

Львовский национальный медицинский университет имени Данила Галицкого ${ }^{2}$

Одесский национальный медицинский университет ${ }^{3}$

yatsyshynaroslav123@ukr.net, lesyakorn@ukr.net,horodetska@gmail.com, Marat.korolev@gmail.com, hromovyk@gmail.com

Цель работы. Установление имеющихся организационно-правовых фрорм субъектов фрармацевтического предпринимательства и анализ особенностей их структуры и локализации в территориально-административных единицах Тернопольской области.

Материалы и методы. Материалы исследования: Реестр мест осуществления деятельности по оптовой и розничной торговле лекарственными средствами (ЛС), статистические данные насчет населения Тернопольской области. Использовано методы информационного поиска, системного и статистического анализа, сравнения и обобщения.

Результаты и обсуждение. Определено, что на территории Тернопольской области по состоянию на 28.02.2020 г. из 290 субъектов предпринимательской деятельности (СПД), имеющих лицензию на оптовую и розничную торговлю ЛС, 257 зарегистрированы на территории области, остальные - в других регионах Украины. Фармацевтическое обеспечение осуществляют 4 аптечных склада, 523 аптеки и 99 аптечных пунктов. Почти три четверти мест розничной реализации ЛС принадлежат СПД, зарегистрированным в Тернопольской области. В городах сосредоточено свыше двух третьих, в т. ч. в г. Тернополь - треть, от всех мест розничной реализации ЛС. Владельцами почти половины аптечных учреждений (АУ) являются фризические лица-предприниматели (ФЛП), свыше двух пятых - общества с ограниченной ответственностью (ООО), остальные - коммунальные и частные предприятия и предприятия коллективной собственности. Лицензию на производство ЛС имеют только 9 аптек. По обеспеченности АУ и плотности населения административно-территориальные единицы Тернопольской области распределились на 8 из 10 кластеров при наличии кластера-лидера - г. Тернополь. Распределение районов имеет значительную асимметрию - низкий уровень обеспеченности АУ характерный для трех, а малая плотность населения - для семи из 17-ти районов.

Вывод. В результате исследования установлено, что: фармацевтическое обеспечение населения Тернопольской области осуществляют СПД различных организационно-правовых фрорм хозяйствования, большинство из которых составляют ФЛП и ООО; в сравнении с прошлым годом количество АУ уменьшилось вследствие существенного сокращения мест осуществления деятельности ФлП; удельный вес сетевых аптек составляет треть от всех СпД фрармацевтического рынка Тернопольской области, а по количеству мест осуществления деятельности их вдвое больше; в сельской местности размещены менее трети АУ, что превышает аналогичный показатель по Украине; только 1,4 \% АУ имеют лицензию на производство ЛС, что на 0,2 \% меньше, чем в среднем по Украине; обеспеченность АУ в сельской местности в 2,8 раза ниже, чем в городской; наблюдается существенная дифрференциация административно-территориальных единиц по обеспеченности АУ и плотности населения.

Ключевые слова: Тернопольская область; административно-территориальные единицы; обеспеченность аптечными учреждениями; плотность населения.

ISSN 2312-0967. Фармацевтичний часопис. 2020. № 2 


\section{Список бібліографрічних посилань}

1. Дмитрик Е. Инфрраструктура аптечного ритейла: на пороге изменений. Еженедельник Аптека. 2019. № 4 (1175). URL: http://www.apteka.ua/article/487942

2. Кіт Л. 3. Організаційно-економічні засади розвитку аптечних мережевих бізнес-структур : дис. ... канд. екон. наук : 08.00.04. Мукачево, 2018. С. 62, 63, 74, 82. URL: https://msu.edu.ua/wp-content/ uploads/2018/12/\%D0\%94\%D0\%B8\%D1\%81\%D0\%B5 \%D1\%80\%D1\%82\%D0\%B0\%D1\%86\%D1\%96\%D0\%B 9\%D0\%BD\%D0\%B0-\%D1\%80\%D0\%BE\%D0\%B1\%D 0\%BE\%D1\%82\%D0\%B0-\%D0\%9A\%D1\%96\%D1\%82\%D0\%9B.\%D0\%97.18.01.2019-\%D1\%80..pdf.

3. Порев С. П. Університет і наука. Епістемологія, методологія і педагогіка виробництв знань : монографрія. Київ : Хімджест, 2012. 382 с.

4. Реєстр місць провадження діяльності з оптової та роздрібної торгівлі лікарськими засобами. URL: http://portal.diklz.gov.ua/PublicSite/TradeLicense/ TradeLicenseList.aspx.

\section{References}

1. Dmitrik E. [Pharmacy retail infrastructure: on the verge of change]. Ezhenedelnyk Apteka. 2019;4(1175). [Electronic resource] Available from: http://www.apteka.ua/ article/487942. Russian.

2. Kit LZ. Organizational and economic principles of development of pharmaceutical networking business structures. Candidate's thesis. Mukachevo; 2018. Available from: https://msu.edu.ua/ wp-content/uploads/2018/12/\%D0\%94\%D0\%B8\%D 1\%81\%D0\%B 5\%D 1\%80\%D 1\%82\%D0\%B 0 \% D 1\%86\% D 1\% 96\%D 0\%B 9\%D 0\%BD\%D 0\% B 0-\%D1\%80\%D0\%BE\%D0\%B1\%D0\%BE\%D $1 \% 82 \%$ D 0 \% B 0-\%D0\%9A\%D1\%96\%D1\%82\%D0\%9B.\%D0\%97.18.01.2019-\%D1\%80..pdf. Ukrainian.

3. Porev SP. University and science. Epistemology, methodology and pedagogy of knowledge production: a monograph [Університет і наука. Епістемологія, методологія i педагогіка виробництв знань: монографрія]. Kyiv: Himgest; 2012. Ukrainian.

4. Register of locations for wholesale and retail trade of drugs [Реєстр місць провадження діяльності 3 оптової та роздрібної торгівлі лікарськими
5. Стратегія розвитку Тернопільської області на період до 2020 року. URL: http://www.oda.te.gov.ua/data/upload/publication/main/ua/20090/strateg2020z.pdf.

6. Чисельність наявного населення Тернопільської області на 1 січня 2019. URL: http://www.te.ukrstat. gov.ua/files/Bul/nm z1 2018.pdf.

7. Чому закриваються аптеки в Україні - цікавиться срармацевтична асоціація. Щотижневик Аптека. 2020. № 9 (1230). URL: https://www.apteka.ua/article/536089

8. Яцишин Я. І., Корнієнко О. М. Дослідження структури суб'єктів підприємництва, що здійснюють фрармацевтичне забезпечення населення Тернопільської області. Формування національної лікарської політики за умов впровадження медичного страхування: питання освіти, теорії та практики: матеріали V Всеукр. наук.-освіт. Internet конфр., 12-13 берез. 2019 р. Харків : С. 350351.

засобами]. Available at: http://portal.diklz.gov.ua/PublicSite/TradeLicense/TradeLicenseList.aspx Ukrainian.

5. Development strategy of Ternopil oblast until 2020 [Стратегія розвитку Тернопільської області на період до 2020 року]. Available from: http://www.oda. te.gov.ua/data/upload/publication/main/ua/20090/strateg2020z.pdf. Ukrainian.

6. Population of Ternopil oblast as of January 1, 2019. [Стратегія розвитку Тернопільської області на період до 2020 року] Available from: http://www. te.ukrstat.gov.ua/files/Bul/nm_z1_2018.pdf. Ukrainian.

7. Why pharmacies are being closed in Ukraine - the pharmaceutical association is interested. Shchotyzhnevyk Apteka. 2020;9(1230) [Electronic resource] Available from: https://www.apteka.ua/article/536089.

8. Yatsyshyn YI, Korniyenko OM. Research on the structure of business entities, which provide pharmaceutical support for the population of Ternopil oblast. Formation of the national medical policy in the conditions of introduction of health insurance: issues of education, theory and practice: materials of the V All-Ukrainian scientificeducational Internet conference, 2019 March 12-13; Kharkiv. 2019. p. 350-351. Ukrainian.

\section{Відомості про авторів}

Яцишин Я. І. - провізор-інтерн, ТзОВ «Аптека № 28 м. Львова», Україна. E-mail: yatsyshynaroslav123@ukr.net.

Корнієнко О. М. - канд. фрармац. наук, доцент кафедри організації та економіки фрармації, Львівський національний медичний університет імені Данила Галицького, Львів, Україна. E-mail: lesyakorn@ukr.net, ORCID 0000-0002-64719300.

Городецька І. Я. - канд. фрармац. наук, доцент кафедри організації та економіки фрармації, Львівський національний медичний університет імені Данила Галицького, Львів, Україна. E-mail: horodetska@gmail.com, ORCID 0000-00030265-5505.

Корольов М. В. - асистент кафедри фрармації, Одеський національний медичний університету, Одеса, Україна. Еmail: Marat.korolev@gmail.com.

ISSN 2312-0967. Pharmaceutical review. 2020. № 2 
Організація роботи аптечних підприємств

Organization of pharmaceutical structures' work

Громовик Б. П. - д. фрармац. наук, професор, завідувач кафедри організації та економіки фрармації, Львівський національний медичний університет імені Данила Галицького, Львів, Україна. E-mail: hromovyk@gmail.com, ORCID 0000-0002-6459-6021.

Information about the authors

Yatsyshyn Y. I. - Pharmacist-intern, LLC Pharmacy No. 28, Lviv, Ukraine. E-mail: yatsyshynaroslav123@ukr.net.

Korniyenko O. M. - PhD (Pharmacy), Associate Professor of the Department of Organization and Economics of Pharmacy, Danylo Halytsky Lviv National Medical University, Lviv, Ukraine. E-mail: lesyakorn@ukr.net, ORCID 0000-00026471-9300.

Horodetska I. Ya. - PhD (Pharmacy), Associate Professor of the Department of Organization and Economics of Pharmacy, Danylo Halytsky Lviv National Medical University, Lviv, Ukraine. E-mail: horodetska@gmail.com, ORCID 00000003- 0265-5505.

Korolyov M. V. - Assistant of the Department of Pharmacy, Odesa National Medical University, Odesa, Ukraine. Email: Marat.korolev@gmail.com.

Hromovyk B. P. - DS (Pharmacy), Professor, Head of the Department of Organization and Economics of Pharmacy, Danylo Halytsky Lviv National Medical University, Lviv, Ukraine. E-mail: hromovyk@gmail.com, ORCID 0000-0002-6459-6021. 